\title{
1. INTRODUCTION: GEOLOGIC STUDIES OF THE CARIBBEAN SEA ${ }^{1}$
}

\author{
Shipboard Scientific Party ${ }^{2}$
}

\section{OVERVIEW}

The Caribbean region poses a wide array of geologic questions, owing to its relatively uncertain plate tectonic evolution, the nature of its largely unsampled oceanic crust or basement, and its important role in global ocean circulation. With the exception of Deep Sea Drilling Project (DSDP) Site 502, the Caribbean had not been targeted by the Ocean Drilling Program (ODP) or DSDP for more than two decades. A fresh impetus to Caribbean drilling was provided by the recent discovery of a strewn field of unaltered impact glass spherules or tektites in Haiti and Mexico at the Cretaceous/Tertiary boundary, and the identification of their source in the 180- to $300-\mathrm{km}$-wide Chicxulub impact crater on the Yucatan Peninsula. Leg 165 drilling was intended to address two major themes: the nature of the Cretaceous/Tertiary $(\mathrm{K} / \mathrm{T})$ boundary $(65 \mathrm{Ma})$, and the influence of tropical seas on global ocean history and climate evolution. In addition, several of the proposed deeper holes held the prospect of reaching basement and, hence, providing new clues to the early formation of the Caribbean Plate. Drilling at five ODP sites (998, 999, 1000, 1001, and 1002) has provided an excellent marine record representing nearly $80 \mathrm{~m}$.y. of Earth history (Fig. 1). It has also led to the unexpected discovery of several major episodes of explosive volcanism in the Caribbean region, and the recovery of an important succession of submarine basaltic lava flows of the Caribbean Oceanic Plateau.

\section{PRINCIPAL OBJECTIVES Cretaceous/Tertiary Boundary}

The principal hypothesis put forward to account for the worldwide $\mathrm{K} / \mathrm{T}$ boundary mass extinctions is the impact of a large bolide on the Earth (Alvarez et al., 1980). The recent discovery of fresh impact glasses at the K/T boundary in the Beloc Formation of Haiti (Sigurdsson et al., 1991b; Izett, 1991), in the Mimbral sequence of northeastern Mexico (Margolis et al., 1991), and at DSDP Sites 536 and 540 in the Gulf of Mexico (Alvarez et al., 1992) provides evidence for a major impact event in the Caribbean region. Geochemical evidence from these glasses also yields constraints for an impact site on continental crust overlain by evaporite-rich sediments (Sigurdsson et al., 1991a, 1992), which is consistent with the stratigraphy near the 180-km (Hildebrand et al., 1991) to 300-km (Sharpton et al., 1994) Chicxulub impact crater on the Yucatan Peninsula of Mexico (Fig. 1). The discovery of glass-bearing impact deposits in the circum-Caribbean region provides a unique opportunity to piece together a more detailed account of the processes responsible for one of the largest environmental disasters in Earth's history. What were the circumstances and the conditions that made this impact event so unique? What were the environmental consequences of this immense impact,

'Sigurdsson, H., Leckie, R.M., Acton, G.D., et al., 1997. Proc. ODP, Init. Repts. 165: College Station, TX (Ocean Drilling Program).

${ }^{2}$ Shipboard Scientific Party is given in the list preceding the Table of Contents. and why was it so detrimental to so many forms of life? Did a sharp cooling episode occur after the impact as a consequence of ejectainduced darkness, and what was its duration? Does evidence exist for a subsequent greenhouse warming?

The major outstanding issue regarding the $\mathrm{K} / \mathrm{T}$ boundary event is the exact relationship between the bolide impact and the associated extinctions. This issue relates to bolide size, impact angle, ejecta dispersal, and, perhaps most important, the geochemistry of the impact terrain. The Yucatan terrain has geologic features that are likely to have brought about uniquely severe environmental effects from the impact. Evidence from the geochemistry of impact glasses or tektites indicates that two dominant geologic formations were melted: (1) Paleozoic continental crust (producing black, high-silica tektite glasses), and (2) Cretaceous evaporites and carbonates (producing sulfurrich, high-Ca yellow glasses; Sigurdsson et al., 1991a, 1991b; Koeberl and Sigurdsson, 1992). Drilling in the Caribbean region addressed a number of problems associated with the $\mathrm{K} / \mathrm{T}$ boundary event, as discussed below.

\section{Total Ejecta Mass and Dispersal Mechanisms}

Ejecta from the bolide impact consists of three principal components: (1) melt ejecta, in the form of impact glass spherules or tektites; (2) gasses from vaporized target material (predominantly water, $\mathrm{CO}_{2}$, and $\mathrm{SO}_{2}$ ), which have converted to a stratospheric aerosol; and (3) crustal rock ejecta or "dust," consisting of proximal breccia and distal crystal fallout (shocked quartz, etc.). Estimates of total ejecta mass range from $2 \times 10^{19} \mathrm{~g}$ (Alvarez et al., 1980) to $1.9 \times 10^{20} \mathrm{~g}$ (Roddy et al., 1991), based on the Ir anomaly and crater size. The variation in deposit thickness is best fitted by two linear segments (Fig. 2A), suggesting that the distribution represents two dominant modes of dispersal. In this model, approximately $99 \%$ of the ejecta occurs within $1400 \mathrm{~km}$ of the impact site (1.2\% of the Earth's surface), whereas the remaining $<1 \%$ is distributed over the remaining surface (Fig. 2B). Thus, the mass loading of solid ejecta fallout on most of the Earth's surface is estimated to be about $0.27 \mathrm{~g} / \mathrm{cm}^{2}$. In comparison, Pollack et al. (1983) adopted a $1 \mathrm{~g} / \mathrm{cm}^{2}$ mass loading of "dust" in their assessment of the climatic effects of $\mathrm{K} / \mathrm{T}$ boundary impact ejecta. These results suggest that previous estimates of a high atmospheric mass loading at the K/T boundary caused by large amounts of rock "dust" may be high by a factor of 4 , and that rock "dust," therefore, was probably not a major climate-forcing factor in the wake of the impact.

Leg 165 drilling will provide much-needed constraints on the ejecta distribution and the dispersal pattern (Fig. 2A). Most current models assume an axisymmetric distribution of the ejecta blanket deposit, but the recent proposal by Schultz (1994) that the Chicxulub structure represents an oblique impact implies that the ejecta distribution would be asymmetric. The fan-shaped distribution of proposed drill sites may help address this hypothesis. The additional recovered sections of the $\mathrm{K} / \mathrm{T}$ boundary will be important for assessing the role of depositional mechanisms in the formation of unique $\mathrm{K} / \mathrm{T}$ boundary lithologies. 


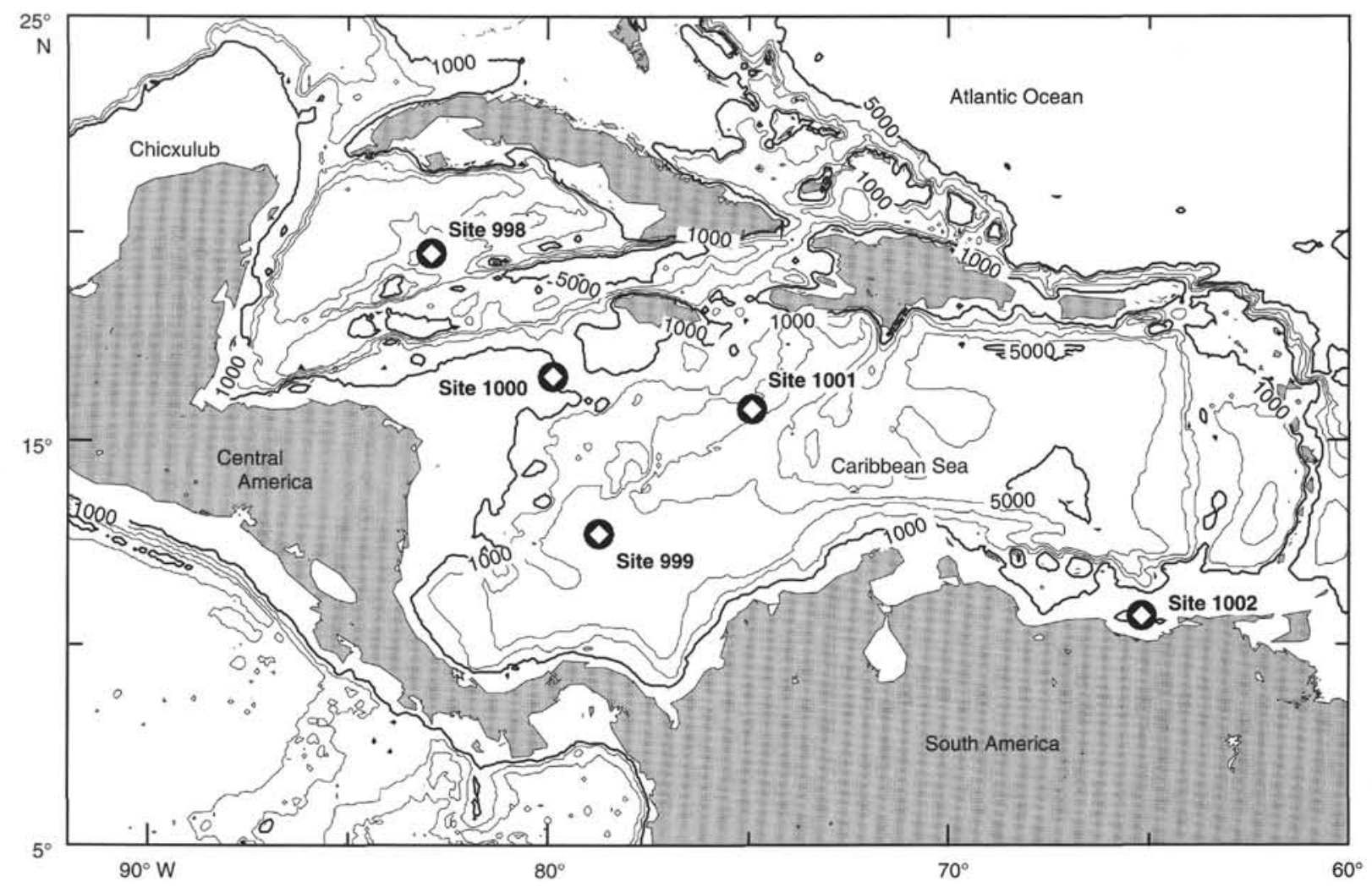

Figure 1. Location of sites drilled during Leg 165.

\section{Volatile Components and Extinction Mechanisms}

The geochemical evidence from the Haiti impact glasses or tektites shows that volatile emission from the target rocks was an important feature of the $\mathrm{K} / \mathrm{T}$ boundary event, and that this feature may account for the uniquely severe environmental effects and high extinction rate that mark the boundary (Sigurdsson et al., 1992). The high sulfur content (up to $1 \mathrm{wt} \%$ ), high oxygen fugacity (Óskarsson et al., 1991), and sulfur isotopic composition of the high-Ca yellow impact glasses (Chaussidon and Sigurdsson, 1994) are conclusive evidence of their formation by fusion of evaporite and carbonate in the presence of a silicate melt. The geologic constraints indicate that the impact volatilized sedimentary rocks and pore fluids to produce a large stratospheric vapor plume consisting of a potent brew of $\mathrm{CO}_{2}, \mathrm{SO}_{2}$, and $\mathrm{H}_{2} \mathrm{O}$ in about equal proportions. These inferences are fully supported by the geologic evidence of the Cretaceous stratigraphy of the Yucatan Peninsula, which contains a $3-\mathrm{km}$-thick succession of evaporite and carbonate sediments at the site of impact (Lopez Ramos, 1981). The atmospheric loading from an impact-generated sulfate aerosol is thus equal to, or possibly greater by an order of magnitude than, the rock "dust" lofted by the impact. It seems very likely that a very large sulfate aerosol must have formed after impact, with major global surface cooling. Because of the prodigious amount of $\mathrm{CO}_{2}$ released, a number of investigators have proposed a sudden, and even harmful, greenhouse warming at the time of impact. However, as indicated by Pollack et al. (1983), in the presence of a dense stratospheric aerosol no warming by a greenhouse effect is possible despite the greatly enhanced infrared opacity of the atmosphere.

The Caribbean drilling sites were chosen to benefit studies of the $\mathrm{K} / \mathrm{T}$ boundary environmental effects. First, the possibilities of coring through complete $\mathrm{K} / \mathrm{T}$ boundary sections seemed likely based on results from DSDP Sites 146 and 152. This, indeed, has proven to be the case. Before Leg 165, only the Haiti site and the Mimbral site in
Mexico had yielded unaltered glass from the boundary. Additional glass samples are needed for further quantitative evaluation of the possible role of evaporites and carbonate sediments in the formation of the impact melt. Second, the recovered boundary deposit may contain fragmentary ejecta from the impacted terrain, such as carbonates and evaporites, that would help elucidate the proportion of chemical sediments in the impacted region. Third, the added information on the thickness distribution of the impact ejecta deposit will help constrain the impact angle and the direction and magnitude of the blast zone. Finally, analyses of microbiota and stable isotopes from wellpreserved marine sediments across the $\mathrm{K} / \mathrm{T}$ boundary will shed light on the environmental changes accompanying the bolide impact.

\section{Late Cretaceous and Cenozoic Ocean-Climate History}

The record of Earth's history is punctuated by episodes of abrupt change. Some events are truly episodic, such as the catastrophic environmental consequences caused by the impact of a meteorite or comet $65 \mathrm{~m} . \mathrm{y}$. ago. Many other events, however, are the result of complex internal feedbacks within the ocean-climate system and thus are related to a variety of processes, including (1) long-term tectonic and volcanic activity, such as the opening or closing of critical circulation gateways or the degassing of $\mathrm{CO}_{2}$; (2) surficial processes such as weathering of the landmasses and hydrothermal activity on the seafloor; and (3) biogeochemical cycling of carbon including export production and other processes of the "biological pump." External forcing caused by cyclical changes in the latitudinal distribution of solar radiation is also an important catalyst of internal feedbacks in the ocean-climate system. Because these internal feedbacks are most likely nonlinear in their relationship to the external forcings, as well as to themselves, it is only with detailed study of many ocean basins that a quantitative understanding of the globally linked ocean-climate system will be reached. 

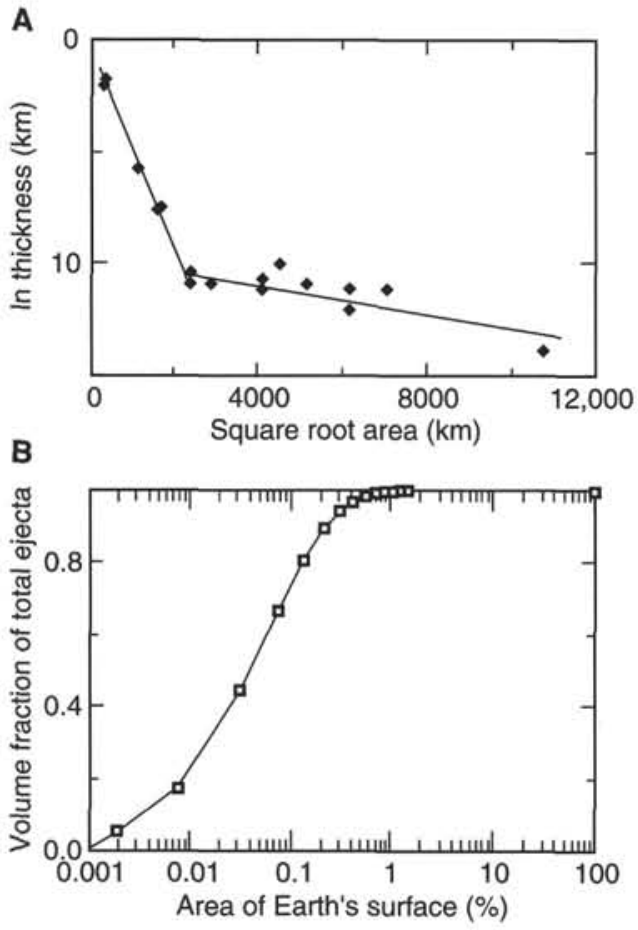

Figure 2. A. The global thickness distribution of the $\mathrm{K} / \mathrm{T}$ boundary ejecta deposit (data from Hildebrand and Stansberry, 1992). The thickness distribution can best be represented as a two-segment plot, in the form of the natural logarithm of the thickness vs. square root of isopach area. An assumption is made that the thickness isopachs are circular in shape. The intersection of the two segments is at a distance of $1400 \mathrm{~km}$ from the Chicxulub impact crater. B. Distribution of the $\mathrm{K} / \mathrm{T}$ boundary impact fallout on Earth. The vast majority of the ejecta is within a $1400-\mathrm{km}$ radius of the Chicxulub crater, or on $1.2 \%$ of the Earth's surface. The distal ejecta fallout represents an atmospheric mass loading per area of about $0.27 \mathrm{~g} / \mathrm{cm}^{2}$.

A major goal of Leg 165 was to sample deep-sea sediments to examine the nature of climate variability and changes in ocean circulation under a variety of boundary conditions present during Late Cretaceous and Cenozoic time. Such sediments provide data for testing hypotheses concerning the role of the tropical ocean in environmental change and climate forcing. For example, what forcing factors caused global warming in the past? What role did greenhouse gases such as $\mathrm{CO}_{2}$ play? How differently did the ocean-climate system operate under conditions of moderate to extreme warmth? Could enhanced oceanic heat transport account for exceptional high-latitude warmth? What types of conditions resulted in abrupt climate change and reorganization of ocean circulation in the geologic past? How did marine microbiota respond to episodes of abrupt change? What was the nature of marine productivity under different ocean-climate states?

The diverse scientific objectives addressed by Leg 165 relevant to the role of the tropics in the ancient ocean-climate system include the following:

1. Climatic and paleoceanographic significance of low-latitude seasurface temperatures and changes in equator-to-pole temperature gradients throughout the late Mesozoic and Cenozoic.

In the absence of significant polar ice and with a different ocean basin configuration, Cretaceous and early Paleogene deep-ocean circulation may have operated in a very different fashion from today's thermohaline circulation. Bottom-, deep-, and/or intermediate-water masses may have formed by the sinking of warm saline tropical waters on the broad shelves or in the epicontinental seas bordering Tethys (Arthur and Natland, 1979; Brass et al., 1982; Saltzman and Barron, 1982; Wilde and Berry, 1982). This mode of deep-water for- mation is widely suspected to have been important, if not dominant, during the mid- to Late Cretaceous and during part of the Paleogene (e.g., Arthur et al., 1985; Kennett and Stott, 1990, 1991; Bralower et al., 1993; Huber et al., 1995). Warm saline deep-water formation is consistent with global circulation modeling of Cretaceous oceans and climate, which suggests strong precession-scale variation in evaporation-precipitation balances over low- and mid-latitude epicontinental seas (Barron et al., 1985; Glancy et al., 1986, 1993; Oglesby and Park, 1989; Park and Oglesby, 1991). Nevertheless, it has yet to be conclusively demonstrated as an important mechanism of deep-water formation during mid- to Late Cretaceous time.

Warm surface-water temperatures persisted in the southern high latitudes from Turonian through early Campanian time (Huber et al., 1995). The paleoceanographic conditions of the Late Cretaceous low latitudes, although poorly defined at present, probably played an important role in climate. Possible causes of the relatively high temperature of polar waters include elevated concentrations of greenhouse gases and increased ocean heat transport from low to high latitudes. The relative importance of these factors can be assessed by isotopic documentation of tropical sea-surface temperatures (SSTs; e.g., Crowley and North, 1991). Were levels of atmospheric $\mathrm{CO}_{2}$ elevated throughout Late Cretaceous time and responsible for warm greenhouse climates, including greater tropical warmth; or, alternatively, did a different mode of oceanic circulation transport more heat to the polar regions? The tropical SSTs might be expected to be higher in the former case, and similar to modern values or perhaps cooler in the latter case.

The first of several major Mesozoic-Cenozoic episodes of cooling in the high latitudes began in the mid-Maastrichtian (e.g., Barrera, 1994). The late Paleocene witnessed a renewed warming trend that culminated in the early Eocene with the warmest high-latitude surface-water and high- and low-latitude deep-water temperatures, and the highest sea level of the Cenozoic (e.g., Dawson et al., 1976; Savin, 1977; Haq et al., 1987; Wolfe, 1985; Miller et al., 1987; Rea et al., 1990; Zachos et al., 1994). Some oxygen isotope data suggest that early Eocene low-latitude sea-surface waters may have been slightly cooler or saltier than those of present-day equatorial oceans (Boersma and Shackleton, 1981; Zachos et al., 1990, 1994).

The nature of climatic forcing during times of exceptional highlatitude warmth, such as the Late Cretaceous and early Eocene, and the reasons for subsequent cooling remain uncertain (Zachos et al., 1994). Climate models have been used to test for changes in the effectiveness of meridional heat transport by ocean and atmosphere with changes in paleogeography and oceanic gateways, as well as climate forcing by changes in the concentration of greenhouse gases in the atmosphere (Rind and Chandler, 1991; Barron et al., 1993; Sloan et al., 1995). The determination of tropical SSTs will help test the validity of greenhouse-forcing models for times of global warmth.

2. The tropical record of abrupt change in the ocean-climate system (e.g., near the Paleocene/Eocene boundary).

A transient episode of rapid warming during latest Paleocene time occurred within a longer term interval of increasing temperatures that culminated in the early Eocene (Zachos et al., 1993). Southern highlatitude surface and deep waters abruptly warmed by $5^{\circ}-6^{\circ} \mathrm{C}$ in less than 10,000 yr (e.g., Miller et al., 1987; Rea et al., 1990; Kennett and Stott, 1990, 1991; Zachos et al., 1993). The "late Paleocene thermal maximum" (LPTM) is also marked by a large negative carbon isotopic excursion. A major extinction event in deep-sea benthic foraminifers coincides with the oxygen and carbon isotope excursions (Tjalsma and Lohmann, 1983; Thomas, 1990, 1992; Zachos et al., 1993). This short-lived event has been attributed to a rapid reorganization of deep-ocean circulation. Warm saline deep waters originating in the tropics, much like the circulation pattern suspected for part of the mid- and Late Cretaceous interval, may have caused the warming event and extinctions. What role, if any, did the tropical ocean play in the onset or demise of abrupt climatic events, and how did this region respond to rapid changes in global climate and/or oceanic circu- 
lation? Drilling in the Caribbean should provide material suitable to test the hypothesis of warm saline deep waters and the nature of deepwater circulation in the Paleogene.

\section{The nature of cyclicity and orbital forcing in the ancient record.}

Caribbean sediments contain records of probable Milankovitchscale sedimentary variation (e.g., DSDP Site 146; J. King and S, D'Hondt, unpubl. data). Analysis of sedimentologic and faunal data from these ancient sequences will document the sensitivity of the low-latitude ocean to Milankovitch-band forcing. For example, Caribbean drilling can test the hypothesis that expression of a precessional "double-beat" in the mid-latitude South Atlantic resulted from equatorial dominance in mid-latitude Late Cretaceous paleoceanographic records (Park et al., 1993).

\section{The role of Caribbean tectonics in the evolution of North Atlantic paleoceanography and Northern Hemisphere glaciation during the Neogene.}

Late Neogene ocean circulation and climate change are intimately linked to the tectonic history of the Caribbean and Central America. Closure of the Central American Seaway by means of steplike uplift and final emergence of the Isthmus of Panama is the most obvious example (e.g., Duque-Caro, 1990). The final closure of the Central American Seaway is expected to have significantly strengthened the Western Boundary Current, diverted northward large volumes of warm and salty waters, and increased the production of North Atlantic Deep Water (NADW) (e.g., Raymo et al., 1989; Maier-Reimer et al., 1990). In addition, the Aves Swell and northern Nicaraguan Rise (NNR) may also have acted as important barriers to ocean circulation in the past (Droxler and Burke, 1995). The development of a strong North Atlantic Western Boundary Current in the Caribbean sometime in the middle Miocene is clearly documented in the Gulf of Mexico and in the Straits of Florida. Intensification of the Loop Current/Gulf Stream circulation during the middle Miocene is supported by numerous observations down-current of the Nicaraguan Rise and Yucatan Strait (e.g., Gomberg, 1974; Mullins and Neumann, 1979; Mullins et al., 1980; Popenoe, 1985; Austin et al., 1986; Denny, 1992; Denny et al., in press). At the same time in the tropical Pacific, a carbonate dissolution event, referred to as the late Miocene "carbonate crash," has been attributed to tectonic shoaling of the Central American Seaway sill (Farrell et al., 1995; Lyle et al., 1995). Recovery of cores in the Caribbean basins north and south of the Nicaraguan Rise and in a present-day channel of the NNR will be used to test models of Neogene surface and deep circulation related to the opening and closure of gateways and shed new light on mixing of the world ocean and regulation of high-latitude climate.

Drilling in the Caribbean Sea between roughly 900 and $3300 \mathrm{~m}$ water depth will provide new data in the global array of surface-, intermediate-, and deep-water circulation in the tropical ocean. Such drilling will allow us to address several questions of both regional and global paleoceanographic, paleoclimatic, and paleobiological significance: What is the history of the Caribbean Current? When was it established? How has the strength of its flow related to tectonic events within the Caribbean region? How has Neogene variation in the Caribbean Current influenced the evolution of North Atlantic surface-, intermediate-, and deep-water circulation and, consequently, the climate of the North Atlantic Ocean? What has been the evolutionary and ecological response of planktonic biota to the partial demise of the carbonate megabank along the NNR and closure of the Central American Seaway?

\section{The history of variations in intermediate-and deep-water masses in the Caribbean during the late Neogene and Quaternary and implications for global conveyor-belt circulation.}

The presence of relatively shallow sills separating the major basins in the Caribbean makes each basin a sensitive monitor of the history of intermediate waters in the open Atlantic Ocean. Because dif- ferent parts of the Caribbean Sea are silled at depths that presently range from 1400 to $1800 \mathrm{~m}$, sediment deposited in the deep Caribbean basins below, at, and several hundred meters above sill depths is thought to record variation in the flux and mixture of both Antarctic Intermediate Water (AAIW) and Upper North Atlantic Deep Water (UNADW). Outside the Caribbean, at the latitude of the Lesser Antilles, AAIW today ranges in water depths from 800 to $1100 \mathrm{~m}$, and UNADW ranges from 1200 to $2000 \mathrm{~m}$ (Bainbridge, 1981). The relative proportions of these source waters can be monitored by studying carbonate preservation and geochemical proxies of deep-water character (e.g., $\left.\delta^{13} \mathrm{C}, \mathrm{Cd} / \mathrm{Ca}\right)$ in the Caribbean basins. Analyses of late Neogene Caribbean records across the $900-$ to $3300-\mathrm{m}$ water-depth range represented by the primary drill sites should document paleoceanographic linkages between Caribbean surface-water flow and rates of NADW formation, and intermediate-water mass history. In turn, this will shed important light on our understanding of how Caribbean tectonics has influenced the global conveyor of surface- and deep-ocean flow and, hence, the evolution of Neogene climate.

6. The potential linkages between abrupt submillennial climatic events of the northern high latitudes (e.g., Heinrich events, Younger Dryas), modes of deep-water formation, and tropical climate variability through the late Quaternary.

Information on rates and magnitudes of tropical climate change is greatly lacking on interannual to millennial time scales. Recent ODP drilling at Santa Barbara Basin, Saanich Inlet, and Cariaco Basin specifically targets resolving climate change on these time frames. Annually laminated, high-deposition-rate sediments of the anoxic Cariaco Basin provide an important late Quaternary record of tropical ocean and climate variability on these sub-Milankovitch time scales (Hughen et al., in press). The Cariaco Basin is well-situated to record in its sediments a detailed history of trade wind-induced coastal upwelling and fluvial discharge from northern South America, phenomena both related to past changes in the strength and position of the Intertropical Convergence Zone (ITCZ). The basin's location also makes it highly suitable for recording surface-ocean changes that result from changes in the Atlantic's thermohaline conveyor circulation. By their varved nature, the sediments of the Cariaco Basin offer the prospect of examining how short-term climate sensitivity responds to past changes in large-scale global boundary conditions. The record to be obtained also will provide a well-constrained basis for theoretical and temporal linkage of tropical paleoclimate events and processes of other regions (e.g., Laurentide meltwater events and the Younger Dryas cold event in the North Atlantic Basin).

\section{Caribbean Oceanic Plateau}

Large oceanic plateaus have long remained curious enigmas within the general understanding of ocean crust formation. Recent ODP drilling in the Indian and Pacific ocean basins has documented the volcanic origin of the Kerguelen (Legs 119 and 120) and Ontong Java (Leg 130) Plateaus. These huge provinces ( 10 million $\left.\mathrm{km}^{3}\right)$ appear to have been formed over brief periods of intense volcanism (e.g., Tarduno et al., 1991) and are likely to be the oceanic equivalents of continental flood basalt provinces. Development of these provinces may be caused by the massive, initial eruptive phase of plumes rising from the deep mantle (e.g., Courtillot and Besse, 1987; Richards et al., 1989). A better understanding of large igneous provinces (LIPs) carries implications for crustal accretion, global elemental fluxes, and mantle composition and circulation.

Early marine geophysical surveys in the Caribbean led to the recognition that a large area was underlain by anomalously thick oceanic crust (e.g., Officer et al., 1957). In an effort to explain the large thickness of crust and corresponding great depth to the Moho (up to $16 \mathrm{~km}$ below sea level), Edgar, Saunders, et al. (1973) proposed that the Caribbean was an area of extensive intrusion by primary basaltic magma. A conspicuous feature of the Caribbean crust is the existence 
of laterally extensive acoustic reflectors that show up on seismic profiles in the Colombian and Venezuelan basins. Two prominent horizons ( $A^{\prime \prime}$ and $\left.B^{\prime \prime}\right)$ were mapped and sampled by numerous workers during early DSDP drilling. On DSDP Leg 15 , horizon B" was sampled at five drill sites with recovery of only about $16 \mathrm{~m}$ of basement. The samples consist of basalt that has geochemical characteristics distinct from those of MORB (Edgar, Saunders, et al., 1973). This discovery led to the recognition of a late Turonian-early Coniacian flood basalt event within the Caribbean, of great extent $(600,000$ $\mathrm{km}^{2}$ ) and exceptional thickness (up to $20 \mathrm{~km}$ ), and with volcanism continuing into the early Campanian at DSDP Site 152. Leg 15, therefore, showed that the top of the plateau is the widespread smooth $\mathrm{B}^{\prime \prime}$ seismic reflector.

Plate reconstructions propose that the original Caribbean oceanic crust may have been formed along one of the spreading centers in the Pacific (Burke et al., 1978; Duncan and Hargraves, 1984; Burke, 1988; Donnelly, 1989; Pindell and Barrett, 1990). These authors speculate that voluminous volcanism associated with the onset of the Galapagos hot spot may have created the Caribbean Oceanic Plateau as the Farallon Plate passed eastward over the hot spot. Further evidence that the Caribbean crust represents a LIP comes from the dating of on-land igneous sections that are thought to represent tectonized peripheral parts of the oceanic plateau. These sections have been recognized in Haiti, Curacao, western Colombia, and Costa Rica. ${ }^{40} \mathrm{Ar} /{ }^{39} \mathrm{Ar}$ incremental heating experiments show contemporaneous volcanism at a number of sites during the period 88-90 Ma (Duncan et al., 1994). These dates are similar to the biostratigraphic ages (Turonian-Coniacian) obtained from DSDP Leg 15 sediments (Sites $146,150,151$, and 153), which directly overlie the igneous rocks of horizon B". The limited duration, generally synchronous nature, and widespread distribution of these dates suggests that volcanism may have occurred over a relatively brief period, but with great intensity, and that it affected a very large area.

Additional evidence for the LIP character of the Caribbean can be found in the geochemistry of the basaltic rocks from the interior and margins of the province. The predominant magma type of both the on-land and drilled sections is tholeiitic basalt in major element composition and exhibits flat REE patterns. These are similar to other oceanic plateau basalts from the Ontong Java Plateau and the Nauru Basin. Other less abundant types of magma include LREE-enriched alkali basalts from Haiti, Costa Rica, and DSDP Site 151, and MgOrich basalts, picrites, and komatiites found in western Colombia, $\mathrm{Cu}$ racao, and Costa Rica. The isotopic signature of basalts from the Dumisseau Formation in Haiti and from Gorgona are similar to the plume-related basalts of the Galapagos, thus providing additional support for the origin of the Caribbean LIP in the Galapagos area with subsequent eastward migration and insertion in its present position between North and South America. The high-MgO rocks from the circum-Caribbean are particularly interesting in that they indicate eruption temperatures of up to $1400^{\circ} \mathrm{C}$ and could be associated with as much as $50 \%$ partial melting of the mantle. Although their stratigraphic position is uncertain, there is some indication that they erupted early in the event. Such large degrees of melting, once thought to be restricted to Precambrian times, may be indicative of the early stages of flood basalt events.

Considerable evidence has accumulated in support of the hypothesis that large areas of the Caribbean, as delineated by the presence of horizon B", represent a LIP. Drilling during Leg 165 will help to elucidate the nature of this important crustal province. We hope that this drilling will indicate the age and basalt compositional patterns of the province and help provide a link to tectonized crustal sections of the plateau exposed subaerially along its margins.

\section{Circum-Caribbean Explosive Volcanism}

The interaction of the Caribbean Oceanic Plateau with the surrounding plates has resulted in a colorful history of circum-Caribbean explosive volcanism that approaches in duration the 90-m.y. lifetime of the plateau itself. The steady east-northeast motion of the Caribbean Plate during the Late Cretaceous and Paleogene sustained a long period of volcanism along the now-extinct Greater Antilles Arc, and its current plate motion is associated with intermittent activity along the Lesser Antilles Arc to the east. Long-lived subduction at the western Caribbean Plate boundary continues to generate vigorous magmatic activity in the Central American arc. Tephra layers in Caribbean sediments are by far the best recorders of explosive volcanism in the arcs surrounding the sedimentary basin; and they are, in turn, sensitive indicators of subduction and other tectonic activity. The lithologic character of volcanic ash layers can also be a valuable indicator of proximal and even shallow-water volcanic sources, in the case of volcaniclastic turbidites. The distribution of volcanic ash fall layers is dependent on the patterns of atmospheric circulation above the Caribbean; with the knowledge of the principal upper air wind patterns that affect tephra from major explosive eruptions, the direction of the source region can be estimated (Sigurdsson et al., 1980). We anticipated that volcanic ash layers would be encountered during the drilling during ODP Leg 165, on the basis of some recovery of ash layers on DSDP Leg 15. The magnitude and frequency of volcanic ash layers encountered during Leg 165 at various levels in sediments drilled throughout the Caribbean was a totally unexpected and welcome discovery.

The potential benefits from this find are truly great for a number of reasons. The large number of Cenozoic and Late Cretaceous volcanic ash layers that can now be dated by high-precision ${ }^{40} \mathrm{Ar} /{ }^{39} \mathrm{Ar}$ methods provides a unique opportunity to improve the geomagnetic polarity time scale, and sets the stage for integrated volcanologic, biostratigraphic, paleomagnetic, isotope, and cyclo-stratigraphic studies, which will lead to major improvements in the Cenozoic and Mesozoic time scales.

\section{REFERENCES}

Alvarez, L.W., Alvarez, W., Asaro, F., and Michel, H.V., 1980. Extraterrestrial cause for the Cretaceous-Tertiary extinction. Science, 208:10951108.

Alvarez, W., Smit, J., Asaro, F., Lowrie, W., Margolis, S., Claeys, P., Kastner, M., and Hildebrand, A., 1992. Proximal impact deposits at the Cretaceous/Tertiary boundary in the Gulf of Mexico: a restudy of DSDP Leg 77 sites 536 and 540. Geology, 20(8):697-700.

Arthur, M.A., Dean, W.E., Schlanger, S.O., 1985. Variations in the global carbon cycle during the Cretaceous related to climate, volcanism, and changes in atmospheric $\mathrm{CO}_{2}$. In Sundquist, E.T., and Broecker, W.S. (Eds.), The Carbon Cycle and Atmospheric $\mathrm{CO}_{2}:$ Natural Variations Archean to Present. Geophys. Monogr., Am. Geophys. Union, 32:504 529.

Arthur, M.A., and Natland, J.H., 1979. Carbonaceous sediments in the North and South Atlantic: the role of salinity in stable stratification of Early Cretaceous basins. In Talwani, M., Hay, W., and Ryan, W.B.F. (Eds.), Deep Drilling Results in the Atlantic Ocean: Continental Margins and Paleoenvironment. Geophys. Monogr., Maurice Ewing Ser., Am. Geophys. Union, 3:375-401.

Austin, J.A., Jr., Schlager, W., Palmer, A.A., et al., 1986. Proc. ODP, Init. Repts., 101: College Station, TX (Ocean Drilling Program).

Bainbridge, A., 1981. GEOSECS Atlantic Expedition, Hydrographic Data, 1: Washington (U.S. Govt Printing Office).

Barrera, E., 1994. Global environmental changes preceding the Cretaceous/ Tertiary boundary: early-late Maastrichtian transition. Geology, 22:877880

Barron, E.J., Arthur, M.A., and Kauffman, E.G., 1985. Cretaceous rhythmic bedding sequences: a plausible link between orbital variations and climate. Earth Planet. Sci. Lett., 72:327-340.

Barron, E.J., Peterson, W.H., Pollard, D., and Thompson, S.L., 1993. Past climate and the role of ocean heat transport: model simulations for the Cretaceous. Paleoceanogr., 8:785-798.

Boersma, A., and Shackleton, N.J., 1981. Oxygen- and carbon-isotope variations and planktonic foraminifer depth habitat, Late Cretaceous to Paleocene, Central Pacific. In Thiede, J., Vallier, T.L., et al., Init. Repts DSDP, 62: Washington (U.S. Govt. Printing Office), 513-526.

Bralower, T.J., Sliter, W.V., Arthur, M.A., Leckie, R.M., Allard, D.J., and Schlanger, S.O., 1993. Dysoxic/anoxic episodes in the Aptian-Albian 
(Early Cretaceous). In Pringle, M.S., Sager, W.W., Sliter, M.V., and Stein, S. (Eds.), The Mesozoic Pacific: Geology, Tectonics, and Volcanism. Geophys. Monogr., Am. Geophys. Union, 77:5-37.

Brass, G.W., Southam J.R., and Peterson, W.H., 1982. Warm saline bottom water in the ancient ocean. Nature, 296:620-623.

Burke, K., 1988. Tectonic evolution of the Caribbean. Annu. Rev. Earth Planet. Sci., 16:201-230.

Burke, K., Fox, P.J., and Sengor, A.M.C., 1978. Buoyant ocean floor and the evolution of the Caribbean. J. Geophys. Res., 83:3949-3954.

Chaussidon, M., and Sigurdsson, H., 1994. Sulfur isotope study of high-Ca impact glasses from the $\mathrm{K} / \mathrm{T}$ boundary. New developments regarding the $\mathrm{K} / \mathrm{T}$ Event and other catastrophes in Earth history. LPI Contrib., 825:2122. (Abstract)

Courtillot, V., and Besse, J., 1987. Magnetic field reversals, polar wander and core-mantle coupling. Science, 237:1140-1147.

Crowley, T.J., and North, G.R., 1991. Paleoclimatology: Oxford Monographs on Geology and Geophysics: New York (Oxford Univ. Press).

Dawson, M.R., West, R.M., Langston, W., Jr., and Hutchinson, J.H., 1976. Paleogene terrestrial vertebrates: northernmost occurrence, Ellesmere Island, Canada. Science, 192:781-782.

Denny, W.M., 1992. Seismic stratigraphy and geologic history of mid-Cretaceous through Cenozoic rocks, southern Straits of Florida [M.S. thesis] University of Texas at Austin, Austin, TX.

Denny, W.M., Austin, J.A., and Buffler, R.T., in press. Seismic stratigraphy and geologic history of mid-Cretaceous through Cenozoic rocks, Southern Straits of Florida. AAPG Bull.

Donnelly, T.W., 1989. Geologic history of the Caribbean and Central America. In Bally, A.W., and Palmer, A.R. (Eds.), The Geology of North America-An Overview. Geol. Soc. Am., Geol. of North Am. Ser., A:299-321.

Droxler, A.W., and Burke, K., 1995. Cenozoic gateway opening and closing in the Caribbean: control on inter oceanic and interhemispheric exchange of water masses between the Atlantic and Pacific Oceans. Eos, 76 (Suppl.):53. (Abstract)

Duncan, R.A., and Hargraves, R.B., 1984. Plate tectonic evolution of the Caribbean region in the mantle reference frame. In Bonini, W.E., Hargraves, R.B., and Shagam, R. (Eds.), The Caribbean-South American Plate Boundary and Regional Tectonics. Mem.-Geol. Soc. Am., 162: $81-94$.

Duncan, R.A., Sinton, C.W.. and Donnelly, T.W., 1994. The Caribbean basalt province: an oceanic LIP. Eos, 75:594.

Duque-Caro, H., 1990. Neogene stratigraphy, paleoceanography and paleobiogeography in the northwest South America and the evolution of the Panama Seaway. Palaeogeogr., Palaeoclimatol., Palaeoecol., 77:203234.

Edgar, N.T., Saunders, J.B., et al., 1973. Init. Repts. DSDP, 15: Washington (U.S. Government Printing Office).

Farrell, J.W., Raffi, I., Janecek, T.R., Murray, D.W., Levitan, M., Dadey, K.A., Emeis, K-C., Lyle, M., Flores, J-A., and Hovan, S., 1995, Late Neogene sedimentation patterns in the eastern equatorial Pacific Ocean. In Pisias, N.G., Mayer, L.A., Janecek, T.R., Palmer-Julson, A., and van Andel, T.H. (Eds.), Proc. ODP, Sci. Results, 138: College Station, TX (Ocean Drilling Program), 717-756.

Glancy, T.J., Jr., Arthur, M.A., Barron, E.J., and Kauffman, E.G., 1993. A paleoclimate model for the North American Cretaceous (CenomanianTuronian) epicontinental sea. In Caldwell, W.G.E., and Kauffman, E.G. (Eds.), Evolution of the Western Interior Basin. Geol. Assoc. Can., Spec. Pap., 39:219-241.

Glancy, T.J., Barron, E.J., and Arthur, M.A., 1986. An initial study of the sensitivity of modeled Cretaceous climate to cyclical insolation forcing. Paleoceanogr., 1:523-537.

Gomberg, D., 1974. Geology of the Portales Terrace. Fl. Sci., 37 (Suppl. 1): 15

Haq, B.U., Hardenbol, J., and Vail, P.R., 1987. Chronology of fluctuating sea levels since the Triassic. Science, 235:1156-1167.

Hildebrand, A.R., Penfield, G.T., Kring, D.A., Pilkington, M., Camargo, A.Z., Jacobsen, S.B., and Boynton, W.V., 1991. Chicxulub crater: a possible Cretaceous/Tertiary boundary impact crater on the Yucatán Peninsula, Mexico. Geology, 19:867-871.

Hildebrand, A., and Stansberry, J.A., 1992. K/T boundary ejecta distribution predicts size and location of Chicxulub crater. Lunar Planet. Sci. 23:537-538. (Abstract)

Huber, B.T., Hodell, D.A., and Hamilton, C.P., 1995. Mid- to Late Cretaceous climate of the southern high latitudes: stable isotopic evidence for minimal equator-to-pole thermal gradients. Geol. Soc. Am. Bull., 107:1164-1191

Hughen, K., Overpeck, J.T., Peterson, L.C., and Anderson, R., in press. An analysis of varves and their palaeoclimatic significance in sediments of the anoxic Cariaco Basin, Venezuela. In Kemp, A.E.S. (Ed.), Palaeoclimatology and Palaeoceanography from Laminated Sediments. Geol. Soc. London Spec. Pub.

Izett, G.A., 1991. K/T boundary tektites from near Beloc, Haiti. Lunar and Planet. Sci. Conf. Abstr., 22:625-626. (Abstract)

Kennett, J.P., and Stott, L.D., 1990. Proteus and Proto-oceanus: ancestral Paleogene oceans as revealed from Antarctic stable isotopic results: ODP Leg 113. In Barker, P.F., Kennett, J.P., et al., Proc. ODP, Sci. Results, 113: College Station, TX (Ocean Drilling Program), 865-880.

, 1991. Abrupt deep-sea warming, paleoceanographic changes and benthic extinctions at the end of the Palaeocene. Nature, 353:225229.

Koeberl, C., and Sigurdsson, H., 1992. Geochemistry of impact glasses from the $\mathrm{K} / \mathrm{T}$ boundary in Haiti: relation to smectites, and a new type of glass. Geochim. Cosmochim. Acta, 56:2113-2129.

Lopez Ramos, E., 1981. Geologia de Mexico, Tomo III. (2nd ed.): Mexico City (Univ. Nac. Auton. Mex.).

Lyle, M., Dadey, K.A., and Farrell, J.W., 1995. The late Miocene (11-8 Ma) eastern Pacific carbonate crash: evidence for reorganization of deepwater circulation by the closure of the Panama Gateway. In Pisias, N.G., Mayer, L.A., Janecek, T. R., Palmer-Julson, A., and van Andel, T.H. (Eds.), Proc. ODP, Sci. Results, 138: College Station, TX (Ocean Drilling Program), 821-838.

Maier-Reimer, E., Mikolajewicz, U., and Crowley, T., 1990. Ocean general circulation model sensitivity experiment with an open Central American isthmus. Paleoceanography, 5:349-366.

Margolis, S., Claeys, P., Alvarez, W., Montanari, A., Swinburne, N., Smit, J., and Hildebrand, A., 1991. Tektite glass from the Cretaceous/Tertiary boundary, proximal to the proposed impact crater in northern Yucatan, Mexico. Geol. Soc. Am. Abstr., A421. (Abstract)

Miller, K.G., Janecek, T.R., Katz, M.E., and Keil, D.J., 1987. Abyssal circulation and benthic foraminiferal changes near the Paleocene/Eocene boundary. Paleoceanography, 2:741-761.

Mullins, H.T., and Neumann, A.C., 1979. Geology of the Miami Terrace and its paleoceanographic implications. Mar. Geol., 30:205-232.

Mullins, H.T., Neumann, A.C., Wilber, R.J., Hine, A.C., and Chinsburg, S.J., 1980. Carbonate sediment drifts in northern Straits of Florida. AAPG Bull., 64:1701-1717.

Officer, C.B., Ewing, J.I., Edwards, R.S., and Johnson, H.R., 1957. Geophysical investigations in the eastern Caribbean: summary of 1955 and 1956 cruises. In Ahrens, L.H., Press, F., Ramhana, K., and Runcorn, S.K. (Eds.), Physics and Chemistry of the Earth, (Vol. 3), New York (Pergamon Press), 17-109.

Oglesby, R.J., and Park, J., 1989. The effect of precessional insolation changes on Cretaceous climate and cyclic sedimentation. J. Geophys. Res., 94:14973-14816.

Óskarsson, N., Steinberg, M., Pradel, P., Helgason, O., Sigurdsson, H., and D'Hondt, S., 1991. Oxygen isotope variation, Mossbauer spectra or iron oxidation and volatile content of tektite glasses from the Cretaceous/Tertiary boundary, Haiti. Lunar and Planet. Sci. Conf. Abstr., 22:1009. (Abstract)

Park, J., D'Hondt, S.L., King, J.W., and Gibson, C., 1993. Late Cretaceous precessional cycles in double time: a warm-Earth Milankovitch response. Science, 261:1431-1434.

Park, J., and Oglesby, R.J., 1991. Milankovitch rhythms in the Cretaceous: a GCM modelling study. Global Planet. Change, 4:329-355.

Pindell, J.L., and Barrett, S.F., 1990. Geologic evolution of the Caribbean region: a plate-tectonic perspective. In Dengo, G., and Case, J.E. (Eds.), The Caribbean Region, Geol. Soc. Am., Geol. North Am. Ser., H:405432.

Pollack, J.B., Toon, O.B., Ackerman, T.P., McKay, C.P., and Turco, R.P., 1983. Environmental effects of an impact-generated dust cloud: implications for the Cretaceous-Tertiary extinctions. Science, 219:287-289.

Popenoe, P., 1985. Cenozoic depositional and structural history of the North Carolina margin from seismic stratigraphic analyses. In Poag, C.W. (Ed.), Geologic Evolution of the United States Atlantic Margin: New York (Van Nostrand Reinhold), 125-187.

Raymo, M.E., Ruddiman, W.F., Backman, J., Clement, B.M., and Martinson, D.G., 1989. Late Pliocene variation in Northern Hemisphere ice sheets 
and North Atlantic deep water circulation. Paleoceanography, 4:413446.

Rea, D.K., Zachos, J.C., Owen, R.M., and Gingerich, P.D., 1990. Global change at the Paleocene-Eocene boundary: climatic and evolutionary consequences of tectonic events. Palaeogeogr., Palaeoclimatol., Palaeoecol., 79:117-128.

Richards, M.A., Duncan, R.A., and Courtillot, V.E., 1989. Flood basalts and hot-spot tracks: plume heads and tails. Science, 246:103-107.

Rind, D., and Chandler, M., 1991. Increased ocean heat transport and warmer climate. J. Geophys. Res., 96:7437-7461.

Roddy, D.J., Schmitt, R.A., and Shuster, S.H., 1991. Asteroid and comet impacts on continental and oceanic sites. Lunar and Planet. Sci. Conf. Abstr., 22:1129-1130. (Abstract)

Saltzman, E.S., and Barron, E.J., 1982. Deep circulation in the Late Cretaceous; oxygen isotope paleotemperatures from Inoceramus remains in DSDP cores. Palaeogeogr., Palaeoclimat., Palaeoecol., 40:167-181.

Savin, S.M., 1977. The history of the Earth's surface temperature during the past 100 million years. Annu. Rev. Earth. Planet Sci., 5:319-355.

Schultz, P.H., 1994. Visualizing the nature and consequences of the Chicxulub impactor: clues from Venus. New developments regarding the $\mathrm{K} / \mathrm{T}$ event and other catastrophes in Earth history. LPI Contrib., 825:104106. (Abstract)

Sharpton, V.L., Marin, L.E., and Schuarytz, B.C., 1994. The Chicxulub multi-ring impact basin: evaluation of geophysical data, well logs, and drill core samples. New developments regarding the K/T Event and other catastrophes in Earth history. LPI Contrib., 825:108-110. (Abstract)

Sigurdsson, H., Bonté, P., Turpin, L., Chaussidon, M., Metrich, N., Steinberg, M., Pradel, P., and D'Hondt, S., 1991a. Geochemical constraints on source region of Cretaceous/Tertiary impact glasses. Nature, 353:839842.

Sigurdsson, H., D'Hondt, S., Arthur, M.A., Bralower, T.J., Zachos, J.C., Fossen, M., and Channell, J.E.T., 1991b. Glass from the Cretaceous/Tertiary boundary in Haiti. Nature, 349:482-487.

Sigurdsson, H., D'Hondt, S. and Carey, S., 1992. Cretaceous/Tertiary bolide impact on evaporite terrane and generation of major sulfuric acid aerosol. Earth Planet. Sci. Lett. 109:543-559.

Sigurdsson, H., Sparks, R.S.J., Carey, S.N., and Huang, T.C., 1980. Volcanogenic sedimentation in the Lesser Antilles arc. J. Geol., 88:523-540.
Sloan, L.C., Walker, J.C.G., and Moore, T.C., Jr., 1995. Possible role of oceanic heat transport in early Eocene climate. Paleoceanography, 10:347356.

Tarduno, J.A., Sliter, W.V., Kroenke, L., Leckie, M., Mayer, H., Mahoney, J.J., Musgrave, R., Storey, M., and Winterer, E.L., 1991. Rapid formation of Ontong Java Plateau by Aptian mantle plume volcanism. Science, 254:399-403.

Thomas, E., 1990. Late Cretaceous through Neogene deep-sea benthic foraminifers (Maud Rise, Weddell Sea, Antarctica). In Barker, P.F., Kennett, J.P., et al., Proc. ODP, Sci. Results, 113: College Station, TX (Ocean Drilling Program), 571-594.

1992. Cenozoic deep-sea circulation: evidence from deep-sea benthic foraminifera. In Kennett, J.P., and Warnke, D. (Eds.), The Antarctic Paleoenvironment: A Perspective on Global Change. Am. Geophys. Union, Antarct. Res. Ser., 56:141-165.

Tjalsma, R.C., and Lohmann, G.P., 1983. Paleocene-Eocene bathyal and abyssal benthic foraminifera from the Atlantic Ocean. Micropaleontol. Spec. Publ., 4.

Wilde, P., and Berry, W.B.N., 1982. Progressive ventilation of the oceans: potential for return to anoxic conditions in the post-Paleozoic. In Schlanger, S.O., and Cita, M.B. (Eds.), Nature and Origin of Cretaceous Carbon-Rich Facies: Academic Press (New York), 209-224.

Wolfe, J.A., 1985. Distribution of major vegetational types during the Tertiary. In Sundquist, E.T., and Broecker, W.S. (Eds.), The Carbon Cycle and Atmospheric $\mathrm{CO}_{2}$ : Natural Variations from the Archean to Present: Am. Geophys. Union Monogr., 32:357-376.

Zachos, J.C., Berggren, W.A., Aubry, M.-P., and Mackensen, A., 1992. Isotope and trace element geochemistry of Eocene and Oligocene foraminifers from Site 748, Kerguelen Plateau. In Wise, S.W., Jr., Schlich, R., et al., Proc. ODP, Sci. Results, 120: College Station, TX (Shipboard Scientific Party), 839-854.

Zachos, J.C., Lohmann, K.C., Walker, J.C.G., and Wise, S.W., Jr., 1993. Abrupt climate change and transient climates during the Paleogene: a marine perspective. J. Geol., 101:191-213.

Zachos, J.C., Stott, L.D., and Lohmann, K.C., 1994. Evolution of early Cenozoic marine temperatures. Paleoceanography, 9:353-387.

\section{Ms 165IR-101}

